\title{
0 Patrimonialismo em Faoro e Weber e a Sociologia Brasileira
}

\author{
Rubens Goyatá Campante
}

obra Os Donos do Poder - Formação do Patronato Político Brasileiro,
de Raymundo Faoro, traz como tema central uma explicação
para as mazelas do Estado e da nação brasileiros: a estrutura de poder
patrimonialista estamental plasmada historicamente pelo Estado
português, posteriormente congelada, transplantada para a colônia
americana, reforçada pela transmigração da Corte lusa no início do
século XIXe transformada em padrão partir do qual se organizaram
a Independência, o Império e a República no Brasil.
Uma imutabilidade histórica, que se constitui através de arranjos in-
timamente relacionados nos campos econômico e sociopolítico. No
primeiro, prevalece o capitalismo politicamente orientado. O Estado
não assume o papel de fiador e mantenedor de uma ordem jurídica
impessoal e universal que possibilite aos agentes econômicos a calcu-
labilidade (termo caro a Weber, amplamente usado por Faoro) de suas
ações e o livre desenvolvimento de suas potencialidades; ao contrá-
rio, intervém, planeja e dirige o mais que pode a economia, tendo em
vista os interesses particulares do grupo que o controla, o estamento.
Não há "regras do jogo" estáveis na economia, pois elas atendem ao
subjetivismo de quem detém o poder político. Esse tipo de capitalis-

DADOS - Revista de Ciências Sociais, Rio de Janeiro, Vol. 46, nº 1, 2003, pp. 153 a 193. 
mo adota do moderno capitalismo a técnica, as máquinas, as empresas, sem lhe aceitar, todavia, a "alma" - a racionalidade impessoal e legal-universal. Um arranjo tradicional, mas maleável em face da modernidade capitalista, a qual aceita seletivamente, mas sem vender a alma - conformada à racionalidade personalista e casuística. $\mathrm{O}$ capitalismo não brota espontaneamente na sociedade, mas vicia-se no estímulo e na tutela estatal: tire-se do capitalismo brasileiro o Estado e pouco ou nada sobrará, adverte Faoro.

Quanto ao segundo aspecto, sociopolítico, Faoro pontua que a sociedade não se organiza, senão subsidiariamente, em classes. A clivagem primordial dá-se entre estamento burocrático e o restante da sociedade, incluindo neste "resto" as camadas proprietárias ou não. Ao contrário da classe social, definida pela agregação de interesses econômicos, determinados, em última instância, pelo mercado, o estamento é uma camada não econômica. Para pertencer a ele, os requisitos são basicamente sociais e políticos, embora, admitam Faoro e Weber, aconteça freqüentemente uma coincidência ou superposição de status econômico e social.

Para Faoro, uma sociedade de classes possui um potencial equalizador e universalista, já uma do tipo estamental privilegia a desigualdade e o particularismo. O estamento é uma camada organizada e definida politicamente por suas relações com o Estado, e, socialmente, por seu modus vivendi estilizado e exclusivista. Não se confunde com a burocracia: "burocrático" é uma qualificação, não a substância; o cargo burocrático é um veículo para a diferenciação social. E, por último, não é, adverte Faoro, uma "elite", nos termos de Mosca, Pareto ou Michels, pois não é uma camada heterônoma e aberta, surgida da "composição patrício-plebéia" que operou nos países capitalistas a partir do século XIX. Ao contrário, é uma estrutura social autônoma e fechada, típica de um "Estado patrício", em que não há uma circulação de baixo para cima.

O instrumento de poder do estamento é o controle patrimonialista do Estado, traduzido em um Estado centralizador e administrado em prol da camada político-social que lhe infunde vida. Imbuído de uma racionalidade pré-moderna, o patrimonialismo é intrinsecamente personalista, tendendo a desprezar a distinção entre as esferas pública e privada. Em uma sociedade patrimonialista, em que o particularismo e o poder pessoal reinam, o favoritismo é o meio por excelência 
de ascensão social, e o sistema jurídico, lato sensu, englobando o direito expresso e o direito a plicado, costuma exprimir e veicular o poder particular e o privilégio, em detrimento da universalidade e da igualdade formal-legal. O distanciamento do Estado dos interesses da nação reflete o distanciamento do estamento dos interesses do restante da sociedade.

Patrimonialismo, estamento e capitalismo politicamente orientado, portanto, são conceitos-chave e inter-relacionados na obra de Faoro. Em termos sociológicos, coube a Max Weber desenvolver tais conceitos, sobre os quais discorrerei a seguir e tentarei salientar a forma como Faoro os utilizou.

\section{PATRIMONIALISMO E ESTAMENTO EM FAORO E WEBER}

Patrimonialismo é a substantivação de um termo de origem adjetiva: patrimonial, que qualifica e define um tipo específico de dominação. Sendo a dominação um tipo específico de poder, representado por uma vontade do dominador que faz com que os dominados ajam, em grau socialmente relevante, como se eles próprios fossem portadores de tal vontade, o que importa, para Weber, mais que a obediência real, é o sentido e o grau de sua aceitação como norma válida - tanto pelos dominadores, que afirmam e acreditam ter autoridade para o mando, quanto pelos dominados, que crêem nessa autoridade e interiorizam seu dever de obediência.

Em razão da instrumentalidade que o estudo do poder exercido sob forma de dominação apresenta na análise sociológica dos "regimes de governo" ,é fundamental, para Weber, a caracterização da dominação social como um poder fundado no mando/obediência psicossocialmente aceitos, distinto do tipo de poder oriundo de "constelações de interesses" organizadas em torno do mercado. Toda dominação, afirma Weber, se manifesta e funciona na forma de governo. Portanto, todo regime de governo precisa do domínio, sua atuação depende de poderes imperativos enfeixados nas mãos de alguém.

Dominação e administração, uma requer a outra, e ambas são necessárias sempre que, minimamente: a) uma organização social se expanda; b) seus membros se diferenciem em termos de poder; c) as tarefas administrativas se tornem complexas. Daí a importância do es- 
tudo dos "meios administrativos". Estudar a administração é estudar a dominação.

No estudo da administração, há que prestar atenção em três fatores intimamente relacionados: a) como se organiza, isto é, como são distribuídos os poderes de mando e obediência, tanto entre os dirigentes e seu pessoal administrativo quanto entre o conjunto dirigentes-quadro administrativo, de um lado, e os dominados em geral, de outro; b) que tipos específicos de tensões e lutas pelo poder uma determinada administração engendra; e, finalmente, o mais importante e influente deles, c) em que princípios últimos repousa a validez das relações de autoridade - a legitimidade.

São três os princípios básicos dessa legitimidade, definidos por Weber no livro Ensaios de Sociologia (1982): o burocrático-legal, o tradicional e o carismático. Conforme a dominação se legitime - e se organize - predominantemente (nas realidades sociais empíricas, os princípios de legitimidade nunca atuam sozinhos, adverte) por meio de um dos tipos ela se adjetiva: dominação burocrático-legal, tradicional ou carismática.

A dominação tradicional subdivide-se em patrimonial e feudal. A dominação patrimonial tem sua legitimidade baseada em uma autoridade sacralizada por existir desde tempos antigos, longínquos. Seu arquétipo é a autoridade patriarcal. Por se espelhar no poder atávico, e, ao mesmo tempo, arbitrário e compassivo do patriarca, manifesta-se de modo pessoal e instável, sujeita aos caprichos e à subjetividade do dominador. A comunidade política, expandindo-se a partir da comunidade doméstica, toma desta, por analogia, as formas e, sobretudo, o espírito de "piedade"1 a unir dominantes e dominados.

O patrimonialismo, portanto, explica a fundamentação do poder político, ou seja, como este se organiza e se legitima, e caracteriza-se pelo poder político organizado através do poder arbitrário/pessoal do príncipe e legitimado pela tradição. Tal legitimação pela tradição é ambivalente em relação à tendência dos dirigentes ao arbítrio pessoal. A tradição, ao mesmo tempo que a ampara, limita-a, ao reconhecer aos dominados certos direitos e imunidades sacralizados pelo tempo e costumes. É a coexistência dinâmica e tensa daquilo que a autora mexicana Gina Zabludovsky Kuper considera o cerne da estrutura patrimonial de poder: o binômio tradição/arbítrio. 
Se o arbítrio predomina, o patrimonialismo aproxima-se do que Weber classificou de patrimonialismo sultanista, ou patriarcal, ou puro. Se prevalece a tradição, o patrimonialismo tende a transformar-se em patrimonialismo estamental ou descentralizado, no qual as relações entre o príncipe e o corpo administrativo são mais estáveis e equalizadas. Para Weber, cada forma de dominação engendra tensões e conflitos específicos na luta pelo poder. O equilíbrio tenso e instável entre tradição e arbítrio e entre governantes centralizadores e quadro administrativo descentralizador é característico dos tipos de dominação tradicional - patrimonialismo e feudalismo. Neste último, ocorre, de forma tão acentuada, uma "apropriação dos meios administrativos" por parte dos "servidores", que acaba por gerar uma situação contratual entre estes e o governante patrimonial, embora não de cunho moderno, formal-objetivo, mas baseada na "honra" subjetiva das partes.

A diferenciação entre patrimonialismo e feudalismo, entretanto, nem sempre é inequívoca. Zabludovsky (1989), por exemplo, destaca a ambigüidade que Weber empresta ao termo patrimonialismo. Geralmente, diz a autora, Weber classifica-o como subtipo de dominação tradicional, ao lado do feudalismo. Às vezes, porém, patrimonialismo é tratado por Weber como sinônimo de dominação tradicional, sendo o feudalismo um "modo" de patrimonialismo, identificado com o "patrimonialismo estamental". Daí a diferenciação feita pela autora entre patrimonialismo em sentido amplo (sinônimo de dominação tradicional, que engloba o feudalismo) e patrimonialismo em sentido estrito (um modo de dominação tradicional, ao lado do feudalismo).

Talvez essa ambigüidade se deva ao fato, para Weber, de o feudalismo possuir, contraditoriamente, tanto elementos tipicamente patrimoniais - como o culto à fidelidade pessoal ao governante - quanto características tipicamente extrapatrimoniais - como a complexa e minuciosa estipulação contratual (mesmo que não-escrita, costumeira) de direitos e deveres entre governantes e quadros administrativos. No primeiro aspecto, configura-se como um tipo de patrimonialismo, embora peculiar; no segundo, extrapola a dominação patrimonial.

Note-se, porém, que Weber, inclusive nesse segundo aspecto, continua a considerar o feudalismo uma variante do patrimonialismo, 
mesmo que um tanto descaracterizado pelas relações não completamente patrimoniais entre príncipe e barões:

"[...] como a relação feudal específica representa [...] uma relação de tipo extrapatrimonial, encontra-se, nesse sentido, além das fronteiras da estrutura patrimonial de dominação. Contudo, é fácil advertir-se que, por outro lado, está tão fortemente condicionada por sua própria atitude de devoção puramente pessoal - relação de piedade - com respeito ao soberano, e oferece de tal maneira o caráter de uma 'solução' a um problema prático do domínio político de um soberano sobre e por meio dos setores patrimoniais locais, que é tratada sistematicamente de modo mais preciso como um 'caso-limite' extremo de patrimonialismo" (Weber, 1992:809, tradução minha).

Duas observações podem ser feitas a partir do trecho acima: os barões feudais fundam seu poder em seus domínios também na relação de "piedade" paterno-filial; o patrimonialismo, para Weber, é definido, por um lado, pelo fundamento da relação de dominação - no caso, a piedade -, mesmo que a relação em si assuma contornos extrapatrimoniais, e, por outro, pela forma como se encaminha a solução do problema de reinar sobre extensões territoriais consideráveis e administrá-las. É nesse sentido que o feudalismo é um "caso particular" ou um "caso-limite" de patrimonialismo e que a melhor forma de se trabalhar o conceito weberiano de patrimonialismo é entendê-lo lato sensu como dominação tradicional que abarca o feudalismo - ou patrimonialismo estamental.

O problema da manutenção do controle pessoal sobre territórios extensos é um dilema típico do governante patrimonial, diante das dificuldades causadas pelas distâncias e precariedade das comunicações e pelos focos de poder locais. Ele o faz por intermédio de "servidores" nem sempre fiéis, que apresentam, não raro, tendências centrífugas. Para o governante patrimonial, o servidor é, ao mesmo tempo, uma "solução" para problemas administrativos e de consolidação do poder central, e uma fonte de problemas e preocupações.

Outra fonte de dor-de-cabeça dos príncipes patrimoniais é o poder dos "notáveis" locais, geralmente grandes proprietários rurais que desejam preservar sua autonomia. No embate entre ambos, assinala Reinhard Bendix (1986:279), normalmente, nem os proprietários rurais nem os governantes conseguem prevalecer definitivamente. Aos primeiros, faltam união e independência completa perante o poder 
central; aos segundos, os recursos privados necessários ao exercício pleno das funções administrativas. O comum, então, são compromissos que legitimam a autoridade dos notáveis locais sobre seus arrendatários, na medida em que isto seja compatível com os interesses fiscais e militares do governante.

Da existência desses conflitos, típicos da dominação patrimonialista, conclui-se que a descentralização, em si, não basta para descaracterizar um arranjo patrimonialista de poder. Os príncipes patrimoniais realmente desejam a centralização, e agem nesse sentido, pois só assim podem exercer o poder de modo pessoal. Porém, os resultados dos tipos de luta pelo poder que ocorrem no patrimonialismo, descritos acima, nem sempre garantem que isso ocorra. Pode haver um enfraquecimento do poder central sem que isso descaracterize o patrimonialismo, que não é, necessariamente, sinônimo de poder centralizado.

E nem sempre uma eventual descentralização distingue o feudalismo. Feudalismo é um caso extremo de descentralização, que chega a ponto de fragmentar, em parte, o caráter patrimonial da relação governante/quadro administrativo, sem, contudo, romper seu fundamento ideológico - a piedade - ou o caráter patriarcal do próprio poder dos barões.

Isso é importante na análise das idéias de Faoro, que concebe nosso patrimonialismo como "sufocante", "tutelador", "sobranceiro", "autônomo" e outros adjetivos que a pontam para um só aspecto: o poder emanando do centro. Para corroborar sua tese, Faoro, então, "torce" às vezes a história brasileira. Admite momentos e tendências centrífugos, mas estes são invariavelmente derrotados e/ou permanecem secundários. Assim, a Guarda Nacional, por exemplo, é entendida como um "agente da política central". Ora, se a Guarda Nacional foi, de fato, instrumento do governo regencial e imperial para implantação e manutenção da ordem estatal, foi, ao mesmo tempo e na mesma proporção, expressão e reforço do poderio do patriciado rural. E (também ao mesmo tempo) expressão da incapacidade de os dois setores, governo e senhores rurais, prevalecerem um sobre o outro, representando uma solução de compromisso, um outro "caso típico" de descentralização ao lado do feudalismo. O que extrema essa descentralização daquela presente no feudalismo é que ela, entre outros motivos, por ser menos profunda que a descentralização feudal, não cria nos potentados uma coesão social baseada na honra estamental. Entre outras coi- 
sas, é a configuração em um estamento honorífico que diferencia senhores feudais de meros "notáveis" rurais.

No amplo estudo tipológico que Weber faz do patrimonialismo, de forma alguma há, entre os tipos extremos do sultanismo (ou patrimonialismo "puro", ou patriarcal) e do feudalismo (ou patrimonialismo estamental), um salto abrupto ou uma passagem automática, mas sim um amplo leque de composições de poder específicas e constantemente tensas. Nessa zona de transição, pensamos, encaixar-se-ia o patrimonialismo brasileiro - tomado em sentido amplo como dominação tradicional: nem patrimonialismo patriarcal (ou "puro") nem feudalismo, com uma camada de notáveis amparando-se na tradição para se autonomizar perante o príncipe.

Faoro, porém, provavelmente temendo que a descentralização comprometa a noção de patrimonialismo e caracterize a de feudalismo, prioriza a proeminência do centralismo na tradição política brasileira. Sua recusa em admitir a descentralização litúrgico-patrimonial como parte da tradição política brasileira tem duas conseqüências: uma é a diminuição da importância histórica do senhoriato rural no Brasil, expressão do poder de classes proprietárias, do poder economicamente condicionado, prefiguração de uma classe social ligada ao comércio internacional e não de um estamento, embora seu poder local repousasse em fundamentos patriarcais. A outra é um tipo de crítica à sua teoria que se equivoca quanto ao conceito weberiano de patrimonialismo ao pretender negar a presença deste no Brasil, apresentando situações históricas, realmente flagrantes, de incapacidade e fraqueza do governo central diante de grupos privados poderosos. Para a teoria de Faoro, isso pode representar problemas, por esse motivo ele minimiza ou omite tais situações. Em termos estritamente weberianos, contudo, a incapacidade ou fraqueza do poder central não desqualifica, em absoluto, uma caracterização patrimonialista do poder no Brasil ${ }^{2}$.

Convém lembrar que outro traço do patrimonialismo, além da descentralização, é a ineficiência governamental. Weber, ao tratar das dificuldades históricas dos príncipes patrimoniais persas e chineses de impor aos grandes comerciantes a cunhagem oficial de moedas, comenta que este exemplo "expressa [...] o alcance extensivo e não intensivo da administração patrimonial" (1992:842). Tal "alcance extensivo" da administração patrimonial é uma característica peculiar e 
contraditória, que costuma acompanhar vários arranjos políticos patrimonialistas: o fato de o governo central ser, ao mesmo tempo, onipresente e fraco. Weber exemplifica ao analisar o sistema fiscal do antigo império patrimonial chinês e salientar que, de toda massa de impostos suportados pelas famílias e aldeias camponesas, apenas uma fatia chegava à Corte do imperador, o restante era dissipado (legal e, principalmente, ilegalmente) ao longo da hierarquia dos funcionários, a despeito de toda vigilância. Entretanto, lembra, tal estrutura patrimonial perdurou durante séculos, em um equilíbrio tenso entre o comando patrimonial vindo de cima e o contrapeso dos funcionários e dos grupos de interesse locais e familiares.

Ou seja, os fundamentos personalistas do poder, a falta de uma esfera pública contraposta à privada, a racionalidade subjetiva e casuística do sistema jurídico, a irracionalidade do sistema fiscal, a não-profissionalização e a tendência intrínseca à corrupção do quadro administrativo, tudo isso contribui para tornar a eficiência governamental altamente problemática no patrimonialismo, especialmente em comparação à eficiência técnica e administrativa que Weber vê em um sistema de poder racional-legal-burocrático. E como tal eficiência é um dos atributos básicos do capitalismo moderno, todos esses fatores mencionados funcionam, também, como um obstáculo à constituição deste em sociedades patrimoniais.

Como vimos, Weber considera que o patrimonialismo, em sua versão tradicionalista e extremamente descentralizada, costuma desenvolver um corpo social que, se lhe é característico, também lhe é contraditório, pois trabalha quase sempre contra o poder pessoal arbitrário do governante. Esse corpo social é o estamento feudal.

O conceito que se contrapõe ao de estamento e, ao mesmo tempo, o baliza é o de "classe". Como foi visto, um estamento é, essencialmente, um grupo social definido por critérios calcados em modelos de status social e não por critérios puramente econômicos, como uma classe $^{3}$. Inicialmente, Stand (estamento, em alemão) ${ }^{4}$ dizia respeito, na Alemanha imperial, basicamente, à hierarquia social e aos níveis sociais mais elevados da população. Weber passa a empregar o termo para designar qualquer grupo social cujas ações veiculassem uma subcultura, um "estilo de vida" particular que fosse importante na compreensão das ações sociais de seus membros. Tal utilização corresponde à necessidade de Weber de explicar a formação de grupos 
sociais e suas ações coletivas não só pela economia, mas também por suas crenças. Segundo Reinhard Bendix, o objetivo de Weber era formular um conceito que abrangesse a influência das idéias sobre a formação de grupos, sem perder de vista as condições econômicas ${ }^{5}$.

O esquema de grupos sociais formados tanto por aquilo que Weber chama "idéias" - crenças de origem não econômicas - quanto por "interesses" - determinantes econômicos - será consubstanciado na relação entre estamentos e religião. Estudando três grandes sistemas religiosos - hinduísmo-budismo, confucionismo-taoísmo e judaísmo-cristianismo -, Weber destaca, na configuração de todos, a importância de estamentos de líderes religiosos. Ele pretende, assim, avaliar não só como cada doutrina religiosa influencia a vida prática dos homens, isto é, sua conduta econômica, mas também estudar como as religiões tomaram rumos específicos de racionalizar a relação entre o humano e o divino em resposta aos interesses concretos dos líderes religiosos, e também de seus seguidores, cujas aspirações eles deviam sempre levar em conta ao erigir o sistema de fé. Ou seja, idéias, realidade econômica e interesses materiais, todos se influenciando reciprocamente, sem que sejam aprioristicamente determinantes uns ou outros.

Uma sociedade estamental é uma "ordem de status" baseada em "prestígio social" para qualificar positiva ou negativamente os grupos sociais. Os grupos positivamente qualificados costumam manter um estilo de vida que desvalora o trabalho físico, o esforço premeditado e contínuo, o interesse lucrativo, e buscam, através de monopólios sociais e econômicos, a manutenção de um modus vivendi exclusivo, diferenciado, traduzido em privilégios de consumo. A razão de ser dos estamentos, portanto, é a desigualdade calcada na diferenciação da honra pessoal, no exclusivismo social e na ostentação do consumo.

Essa noção essencial de estamento como um grupo definido por critérios basicamente sociais, em vez de econômicos, e que tem como premissa a diferenciação e o exclusivismo sociais, está presente em Faoro. Entretanto, enquanto Weber pensa sempre no plural, em estamentos, pois vários grupos sociais podem se estamentalizar, positiva ou negativamente, Faoro usa quase sempre o singular, tão singular que muitas vezes vem desadjetivado: $o$ estamento - e ponto final. $O$ 
estamento, para Faoro, são os donos do poder, o patronato político brasileiro.

Se a estratificação social por estamentos se distingue daquela por classes pelo fato de promover uma diferenciação entre indivíduos baseada não em critérios puramente econômicos, mas de status social, o estamento, então, é um tipo de grupo social e não um grupo social, havendo estamentos positiva e negativamente qualificados em termos sociais. A insistência de Faoro em falar do estamento no Brasil seria como se Marx falasse d $a$ classe, em lugar de mencionar a classe burguesa ou a classe proletária.

Além disso, na combinação dos conceitos de patrimonialismo e estamento - o patrimonialismo estamental -, Faoro afasta-se de Weber. Para o sociólogo alemão, patrimonialismo estamental é um tipo radicalmente descentralizado de patrimonialismo, no qual o poder do príncipe ombreia com o dos barões territoriais, é sinônimo de um tipo de feudalismo - o ocidental -, o mais típico e "puro", desenvolvido até as últimas conseqüências.

Enquanto o estamento de senhores feudais de Weber é um grupo que se origina do patrimonialismo, mas que acaba, em parte, negando-o, o estamento político-burocrático de Faoro tem origem no patrimonialismo e reforça-o. Isso porque o estamento feudal de Weber é senhorial-territorial, atuando em uma economia não ou pouco monetarizada, ligado intimamente ao feudalismo, o qual a presenta uma burocratização reduzida. Já o de Faoro é um estamento burocrático constituído "à ilharga do Estado" em um sistema socioeconômico dominado pelo comércio mercantilista, que nada tem de feudal. O primeiro é vetor de descentralização política; o segundo, de centralização.

Faoro tem plena consciência dessa "infidelidade" ao weberianismo. Considera-a, entretanto, um ajustamento necessário à sua teoria - a heterodoxia à teoria weberiana dever-se-ia a peculiaridades da América Ibérica, na qual "o patrimonialismo se acomoda com uma particularidade, uma particularidade talvez ibérica, talvez ibero-americana. Fora da ordem feudal, os estamentos cresceram e se tornaram visíveis, sem a quebra - o que espantaria Max Weber - da ordem patrimonial" (Faoro, 1993:26).

Faoro constrói, portanto, o seu estamento, ibero-americano, nem feudal nem antipatrimonialista. Talvez por isso, por não enxergar no es- 
tamento um desafio à ordem patrimonial - desafio que, repita-se, é parcial em Weber, para quem o estamento feudal é e não é patrimonialista -, ele descuide de definir melhor as relações, cruciais para Weber, entre estamento e governante patrimonial. Em Os Donos do Poder, ora o príncipe patrimonial é um joguete nas mãos do estamento, como no caso da deposição de D. Pedro II, ora permanece dócil e atado ao poder pessoal do líder.

A ambivalência quanto a essa questão talvez se deva ao fato de a verdadeira dicotomia apontada por Faoro verificar-se não entre quadro administrativo e líder patrimonial - ambos patrimonialistas -, mas entre estes em conjunto e o povo. No esquema explicativo de Faoro sobre o Brasil, ausência de povo é presença constante. Abúlico, o povo brasileiro não constituiu uma sociedade civil contraposta ao Estado. Confrontadas com uma fraqueza popular congênita, as rusgas entre o estamento e o rei (ou o presidente da República) são, na melhor das hipóteses, deixadas em segundo plano, quando não simplesmente ignoradas.

Para Faoro, as liberdades públicas estribam-se nas liberdades econômicas e somente uma estrutura social baseada em classes, expressão do domínio pleno da economia pelo sistema de mercado, pode abrir reais possibilidades para um Estado liberal-democrático. Caso contrário, tem-se o estamento, e o liberalismo e a democracia são superficiais. "Os estamentos florescem, de modo natural, nas sociedades em que o mercado não domina toda a economia, a sociedade feudal ou patrimonial" (Faoro, 1998:23). Ou seja, somente nas sociedades modernas e capitalistas é que o econômico sobrepuja e define o político e o social; nas sociedades atrasadas e pré-capitalistas ocorre exatamente o contrário.

Colocando a questão nos termos: ou sociedade de classes ou de estamentos, Faoro decide, portanto, pela última opção para caracterizar a história brasileira. Há autores, entretanto, que negam a escolha tanto de uma como de outra opção para explicar a sociedade brasileira. Estudaremos, a seguir, o argumento de alguns deles, que, influenciados, de uma forma ou de outra, pela tradição weberiana e a partir de um foco analítico na época do Império, estabelecem um diálogo, direto ou indireto, com as idéias de Faoro sobre a preeminência do estamento e do patrimonialismo na história brasileira. 


\section{PATRIMONIALISMO E ESTAMENTO NA SOCIOLOGIA WEBERIANA BRASILEIRA}

Maria Sylvia de Carvalho Franco, em Homens Livres na Ordem Escravocrata, nega a idéia do Brasil tanto como uma sociedade estamental quanto de classes, a partir de seu estudo sobre a vida de um contingente populacional paulista rural não-escravo e não-proprietário no século passado. A razão para a negação dos estamentos é a de que o critério básico de diferenciação social não era a honra, mas o dinheiro, em um meio humano em que o latifúndio era definido pela produção mercantil. A sociedade brasileira não era tradicional (estavam ausentes a estabilidade, o contratualismo subjetivo, a solidariedade vertical e a estereotipação e diferenciação sociais), mas instável, aberta ao recrutamento, não estereotipada, anticonvencional, em que a vulgarização cultural diminuía a distância social.

Nem por isso chegava a ser uma sociedade de classes. A escravidão impedia não só os cativos, mas principalmente os homens livres e pobres, de verem-se incluídos em uma relação social e econômica propriamente capitalista, por estarem agregados à parte tradicional, não-dinâmica, não mercantil daquela economia - a parte dinâmica e mercantil era justamente a produção escravista. A agricultura mercantil escravista, que os fazia existir, não lhes conferia utilidade social alguma e atava-os ao poder pessoal do latifundiário. Este, entretanto, premido pelo caráter comercial de seu empreendimento, não raro descurava de compromissos éticos de proteção tacitamente assumidos, jogando os desfavorecidos em um mundo instável de anomia e violência sem expressão social.

O poder pessoal autárquico não se refletia exclusivamente no mundo dos pobres, mas também determinava, entre os ricos, uma falta de coesão social que impedia a percepção e o desenvolvimento de projetos coletivos: "ao ter o mundo reduzido a dimensões pessoais, os alicerces mesmos de seu poder determinavam seus limites: quase onipotentes porque fechados em seus pequenos reinos, por isto mesmo mostram-se incapazes de transcendê-los" (Franco, 1976:218).

Trata-se de um universo intrinsecamente contraditório e ambíguo aquele descrito por Franco. De um lado, tem-se a predominância de elementos impessoais na produção mercantil; de outro, a produção direta de meios de vida e o poder privado, que se manifesta inclusive 
na apropriação, por parte dos potentados rurais, dos meios administrativos, fazendo com que o privado se prolongue na vida pública e nesta mantenha a dominação social. Entretanto, salienta Franco, apesar de "possuírem" o Estado, os latifundiários não conseguiam, por seus horizontes limitados pelo personalismo, construir uma esfera pública.

Apesar de distintas, as duas práticas econômicas e sociais - produção direta de meios de vida e produção de mercadorias - estão, na história do país, simbioticamente ligadas e são, como Franco resume, constitutivas uma da outra. Atraso e modernidade mutuamente alimentando-se, mas ao mesmo tempo impedindo que a sociedade possa ser nitidamente caracterizada como "atrasada" ou "moderna".

A negação do caráter estamental da sociedade brasileira, sem que isso defina uma sociedade de classes, contrasta claramente com a tese de Faoro. Franco nega, contudo, que o patriciado rural se tenha transformado em um estamento. A meu ver, não é nesse grupo que está o estamento de Faoro, mas na burocracia encastelada no Estado. De qualquer forma, Franco ressalta a fluidez, a abertura e a não-estereotipação como características (não estamentais) presentes em nossa sociedade, advindas de um arranjo social em que o poder econômico tinha, sim, ao contrário do que nega Faoro, autonomia e força suficientes para determiná-las. O que singularizava esse poderio econômico, porém, era o fato de ele ser umbilicalmente ligado ao mercado externo e só subsidiariamente ao interno. A modernidade, entendida como o mercado impessoal, só penetrava nossa sociedade até determinado ponto e sob impulso externo.

No sentido de negação do estamento, tanto no setor latifundiário quanto na burocracia, há também a obra de José Murilo de Carvalho (1980), que estuda a burocracia imperial brasileira e seu papel decisivo na manutenção das possessões lusas da América em um só Estado - monárquico, civil, estável e conservador. Essa burocracia imperial que "eram várias", assegura Carvalho - não se constituía em estamento sequer em seus níveis mais altos, como o Conselho de Estado, onde política e administração se fundiam, pois não era aquele um Estado feudal ou mercantilista. (Faoro diria que era mercantilista, sim.) Mas tampouco era moderna, no sentido weberiano. A precariedade funcional, a escassa utilização de parâmetros meritocráticos de ascensão, a má estruturação das carreiras, o personalismo, a bajula- 
ção, a cultura do favor, todas estas características patrimoniais lhe negavam peremptoriamente tal qualificação.

Também os latifundiários, segundo ele, não constituíam um estamento, à conta do sistema escravista exportador. Não podiam viver ociosos dos serviços de camponeses, disponibilizando-se para serviços militares/administrativos como a elite inglesa. Eram homens de negócio que não tinham como se dedicar ao governo.

Somada à não-coesão dos latifundiários, havia a tradição de um Estado coeso. Coeso não significa todo-poderoso ou absolutamente eficiente. Mesmo com uma grande capacidade de controle e aglutinação, o Estado imperial brasileiro não era, garante Carvalho, autônomo perante a nação. Assim como a burocracia e a elite que o conformaram, $\mathrm{o}$ Estado tinha a mesma ambigüidade em relação ao latifúndio escravista, uma vez que "dependia profundamente da produção agrícola de exportação e encontrava na necessidade da defesa dos interesses dessa produção um sério limite a sua liberdade de ação" (Carvalho, 1980:126). A questão, assevera o autor, é que o Brasil não era como Portugal, governado por uma aliança entre estamento burocrático e comércio, mas uma economia de produtores agrícolas escravistas e de pecuaristas - escravistas ou não. As bases de poder aqui eram outras, havia um foco de poder independente no latifúndio agrário, algo inexistente em Portugal desde a dinastia de Avis.

Essa ambigüidade foi resolvida, segundo Carvalho, mediante uma solução de compromisso com o poder privado econômico, cujo exemplo era a Guarda Nacional. A nomeação, pelo poder central, de seus membros, assim como dos delegados de polícia - recrutados invariavelmente entre os poderosos locais -, pacificava a conflituosidade local entre esses poderosos e solucionava o problema da manutenção da ordem - pelo menos de um tipo de ordem - em um território tão extenso, problema que o governo central certamente não daria conta sozinho. Os conflitos eram, assim, processados na esfera pública, mas a preço de manter privado o conteúdo do poder. As conseqüências, de efeitos duradouros na história brasileira, eram a estabilidade política, por um lado, e a restrição à cidadania e ao conteúdo público do poder, por outro, em um arranjo em que governar significava reconhecer a estreiteza do poder estatal. 
José Murilo de Carvalho, portanto, contesta a tese de Faoro, na medida em que aponta o caráter não estamental da sociedade brasileira e, especialmente, da burocracia imperial e também considera o patriciado rural como um foco independente de poder. Todavia, no que se refere à questão do patrimonialismo, Carvalho corrobora as teses (de sentido histórico, inclusive) de Faoro, especialmente a do patrimonialismo como uma herança lusa reforçada pelo peculiar processo de Independência brasileiro:

"O clientelismo e o patrimonialismo aportaram a estas plagas nas caravelas lusas. Eram parte integral do Estado metropolitano. Aqui não sofreram qualquer desafio. Pelo contrário. A colonização foi empreendimento estatal, o rei se apossou das terras e as distribuía aos vassalos, assim como distribuía capitanias e delegava funções de governo. Portugal e seu rei mercador não tinham gente suficiente para administrar as novas conquistas e foi necessário recorrer ao concurso dos particulares. Estes, por sua vez, podendo obter mercês e delegações da metrópole, preferiram manter a vinculação patrimonial a rebelar-se. Nossos barões nunca enfrentaram o rei, salvo em alguns ensaios como nas guerras dos senhores de engenho em Olinda contra os mascates do Recife e dos paulistas contra os emboabas em Minas" (Cordeiro e Couto, 2000:24).

A citação acima parece, à primeira vista, contraditória em relação a idéias do próprio Carvalho, quando afirma que nossos barões jamais enfrentaram o rei, sendo que anteriormente ele advertira que o Brasil não era Portugal, pois haveria aqui um foco independente de poder, expresso pelo latifúndio. A contradição, a meu ver, é apenas aparente. Em primeiro lugar, os latifundiários constituírem um foco de poder é uma coisa; enfrentarem diretamente o rei é outra, embora obviamente a autonomia e a solidez possam encaminhar eventuais enfrentamentos. Porém, mais importante é perceber que a contradição, a ambigüidade - mesmo que permanecendo o mais das vezes em estado latente - não estão nas análises de José Murilo de Carvalho, mas na dinâmica do próprio sistema que ele analisa, o patrimonialismo. Segundo Weber, tensões, ambigüidades e contradições entre o poder central, o poder dos funcionários da administração e o poder de potentados locais relativamente autônomos são característicos da dominação patrimonialista, assim como a resolução de tais tensões mediante soluções de compromisso entre tais focos de poder que envolvem vantagens e garantias recíprocas. 
Entretanto, não é apenas esse tipo de contradição que a dominação de tipo patrimonial engendra, segundo a teoria de Weber. Já vimos que de suas entranhas pode nascer, segundo o sociólogo alemão, uma organização de poder feudal-estamental que, ao mesmo tempo, reforça e solapa o patrimonialismo puro. E pode nascer, também, um arranjo de poder que, embora reforce, por um lado, o patrimonialismo, tem afinidade com outro tipo ideal weberiano de dominação, o racional-legal. Este arranjo de poder, contraditório em relação ao patrimonialismo do qual emerge, é o sistema patrimonial-burocrático, muito bem estudado por Fernando Uricoechea na obra O Minotauro Imperial (1978), que caracteriza o sistema político imperial brasileiro a partir da contradição básica entre um impulso modernizante e um contexto político-cultural, do qual brotou esse próprio impulso - tradicionalista.

O Estado brasileiro tem, para Uricoechea, caráter modernizador, na medida em que consegue, de alguma forma, mesmo compactuando com um estrato de proprietários patriarcalistas, estender uma efetiva burocratização e racionalização sobre a sociedade. Esse tipo de argumento parece, à primeira vista, análogo às teorias de Antônio Paim, apresentadas especialmente na obra A Querela do Estatismo (1998), na qual o autor busca chamar a atenção para a dimensão modernizante segundo ele, injustamente esquecida pela maioria dos pesquisadores - do patrimonialismo na tradição política luso-brasileira. Esse "patrimonialismo modernizante" começa com as reformas de Pombal, passa pelos arquitetos da ordem imperial e chega, no século XX, ao Estado Novo e aos governos militares.

De acordo com Paim, Faoro teve o mérito de, através do conceito de patrimonialismo, ser o introdutor e divulgador de um fecundo esquema interpretativo da história e da sociedade brasileiras. No entanto, pondera que Faoro, talvez "ofuscado pela magnitude da própria descoberta", radicalizou sua explicação, transformando o patrimonialismo no Brasil em um determinismo histórico inafastável, além de traçar um juízo severo e injustamente negativo tanto do patrimonialismo, ao não reconhecer a já citada faceta modernizadora do mesmo ${ }^{6}$, quanto do liberalismo do Império - a acusação de elitismo é extemporânea, afirma Paim, pois somente no fim do século XIX houve o processo de democratização da idéia liberal no mundo como um todo. 
Portanto, apesar da coincidência quanto ao reconhecimento de um impulso modernizante no patrimonialismo, a diferença entre as visões de Paim e Uricoechea está em que, para o primeiro, a modernização é um feito do patrimonialismo estatal em si - que ele identifica como "autoritarismo instrumental" - e que aproveita, mesmo que indiretamente, a toda a sociedade, na medida em que a resgata de um exacerbado privatismo. Já para Uricoechea, a modernização deu-se não pelo patrimonialismo, mas apesar dele, e o arranjo político da burocracia patrimonial é instrumentalizado em proveito basicamente de dois estratos da sociedade pactuantes entre si: um aparato administrativo e os grandes proprietários interessados em manter a ordem escravista - pacto cuja origem não se esgota na causa citada por Bendix, qual seja, da impossibilidade relativa tanto de um grupo prevalecer sobre outro, quanto de ser derrotado e/ou cooptado, mas que tem como função primordial a necessidade básica para ambos de manutenção da ordem social e do status quo diante da massa popular de desprivilegiados.

Pode-se argumentar que Faoro já havia salientado o papel intrinsecamente conservador, oligárquico e exclusivista do patrimonialismo, assim como a tibieza do setor popular na história brasileira. A diferença básica, porém, é que Faoro vê na burocracia imperial um estamento centralizador e mantenedor do atraso e do patrimonialismo tradicionalista, enquanto, para Uricoechea, se tal elite burocrático-patrimonial realmente favorecia a constrição social, indo ao encontro do projeto dos latifundiários, ela também foi um vetor de racionalização progressiva da esfera pública - um entendimento que se aproxima mais das análises de José Murilo de Carvalho sobre a burocracia imperial.

Para Uricoechea, o enfraquecimento do sistema de poder do Império, que culmina com o advento da República, e da instituição que o representava - e representava o compromisso entre burocracia estatal e latifundiários, a Guarda Nacional - deve-se ao processo concomitante de organização dos latifundiários em moldes classistas e de transformação do Estado, cada vez mais, em espaço de representação e disputa de interesse em lugar de esfera de solução de compromisso tradicionalista, ou seja, o poder vai se legitimando cada vez mais em moldes racional-burocráticos. 
A presença de grupos sociais organizando-se e atuando politicamente em moldes de representação e competição de interesses econômicos também é detectada por Simon Schwartzman, que tem no conceito de patrimonialismo a ferramenta central de seu modelo interpretativo, expresso na obra Bases do Autoritarismo Brasileiro. Assim como Paim e Uricoechea, Schwartzman matiza o caráter esmagador e estático do patrimonialismo faoriano - a quem critica diretamente por isso. Entretanto, apesar de apresentar o patrimonialismo de maneira mais benévola e menos negativa (citando, inclusive, a advertência de Paim sobre algumas de suas implicações racional-modernizantes), Schwartzman não nega sua primazia e continuidade no desenvolvimento brasileiro. E, mais importante, não nega que ambas estejam relacionadas ao padrão autoritário da política nacional.

É fundamental, para a construção de sua teoria, a análise do que ele denomina "padrão de colonização portuguesa" que se implantou no Brasil. Tal padrão tem como base a dependência externa (já experimentada por Portugal em relação à Inglaterra, após a Restauração, e transferida ao Império recém-formado) para associar, de forma aparentemente curiosa, fortalecimento e centralização política, de um lado, e decadência econômica, de outro. Some-se a essa receita a atenção ao problema regional e tem-se o diagnóstico de Schwartzman: regiões brasileiras como o Nordeste, o Rio de Janeiro e Minas Gerais, que amargaram decadência econômica, vivenciaram, a partir de suas elites, o fortalecimento do patrimonialismo e do sistema político de cooptação autoritária de atores sociais para compensar, extra-economicamente, tal decadência; já São Paulo, região pobre e de tradição autonomista em face do poder central, não conheceu um ciclo econômico de apogeu seguido de decadência, estabelecendo um sistema político de representação classista de atores econômicos no qual o patrimonialismo penetrava com muito menos força.

A questão é que, nacionalmente, o sistema político permaneceu basicamente nas mãos das elites das regiões economicamente decadentes e politicamente patrimonialistas, enquanto a região de economia mais dinâmica, São Paulo, quedou marginalizada politicamente. Assim, Schwartzman, contrariando boa parte da historiografia brasileira, considera, por exemplo, que a República Velha não expressou o domínio da oligarquia cafeeira paulista sobre o Estado brasileiro, mas o contrário. A coalizão de interesses entre as oligarquias rurais e o Estado, que autores como Elisa Reis salientam, é efetiva, mas não ex- 
plica completamente, garante Schwartzman, o quadro do início da República - para tal, é necessário levar em conta que a estrutura política brasileira, predominantemente patrimonialista, tem como característica um esquema que associa dependência externa, autonomia estatal interna e resolução política, elitista e extramercado, dos problemas gerados pela decadência econômica, a favor de certas regiões e em prejuízo de outras.

“O padrão de dependência externa [...] significou, assim, não apenas que os recursos e a riqueza nacional eram canalizados para o exterior, o que é [...] conceitualmente trivial, mas também que, neste processo, o Estado patrimonial foi capaz de sobreviver ao limitar as oportunidades de organização e manifestação política independente por parte de grupos nacionais que detinham uma base produtiva própria [...]. Confrontados com um setor político dominante, que gozava do apoio de interesses econômicos estrangeiros poderosos, os grupos nacionais podiam implorar, pressionar ou reivindicar favores especiais e concessões dos detentores do poder político, mas nunca poderiam aspirar a conquistá-lo e submetê-lo a seus próprios fins. É por isso que a coalizão conservadora dos cafeicultores com o governo federal não teve como resultado, a longo prazo, a subordinação da política federal aos interesses do café, mas ao contrário, a progressiva dependência dos interesses do café em relação ao governo do Rio de Janeiro" (Schwartzman, 1988:101).

No artigo "Elites Agrárias, State-Building e Autoritarismo", espécie de resumo de sua tese de doutorado, Elisa Reis (1982:339) corrobora a afirmativa de Schwartzman de que a permeabilidade do Estado aos interesses rurais-oligárquicos - e somente a tais interesses e de nenhum outro grupo - configura, em última análise, não o domínio, mas a submissão de grupos privados ao poder do Estado. No entanto, o desenvolvimento de seu $\operatorname{argumento}^{7}$ acaba por contestar o de Schwartzman, na medida em que lembra que os cafeicultores paulistas também lançavam mão de fatores políticos para obter benefícios econômicos ${ }^{8}$.

Isso vai de encontro à afirmação de Schwartzman de que no Brasil "o fortalecimento de estruturas políticas não se deu a partir da expansão econômica de determinados setores, mas precisamente em função da decadência de outros" (1988:99). A seguir-se a argumentação de Elisa Reis, tem-se um caso em que o robustecimento de estruturas políticas 
se dá, sim, a partir da expansão econômica de um setor, indicando que, se a correlação entre fortalecimento político (patrimonial) / decadência econômica faz sentido, não subsiste, porém, sozinha na vida nacional, nem tem validade explicativa plena. Elisa Reis afirma, inclusive, que a oligarquia rural paulista da República Velha, com a necessidade do atendimento de suas reivindicações, legitimou de tal forma o poder central que abriu caminho para a modernização autoritária conduzida pelo Estado pós-30.

“No Brasil, o papel das elites agrárias foi [...] contraditório: defendendo a descentralização de poder sob o federalismo, elas paradoxalmente contribuíram para concentrar a autoridade pública. Na medida mesma em que [...] lograram sucesso em diluir a fronteira entre as esferas pública e privada, elas contribuíram para a centralização do poder. Tanto política quanto economicamente, os fazendeiros atuaram de forma a conferir ao Estado o status de ator político privilegiado. Fortalecendo o poder Executivo sobre o Legislativo e o Judiciário, neutralizando a competição política, exigindo a intervenção constante do Estado na economia, a dominação oligárquico-rural abriu caminho para um Estado forte." (Reis, 1982:345) ${ }^{9}$

De qualquer forma, apesar das diferenças, há um ponto básico comum que perpassa as teorias de Schwartzman e Reis: a ausência de um encaminhamento tipicamente burguês e classista do desenvolvimento nacional, baseado na representação de interesses. Este ponto é, de certa forma, óbvio e inúmeros autores salientam-no - inclusive os já citados aqui: José Murilo de Carvalho, Maria Sylvia de Carvalho Franco, Fernando Uricoechea, para não falar do próprio Faoro. O que os diferencia, porém, são as causas apontadas para explicar tal questão. No caso de Schwartzman e Reis, o primeiro oferece como justificação o papel politicamente marginalizado que a região portadora de um modelo de desenvolvimento não baseado na cooptação autoritária patrimonialista tem ocupado na história nacional; a segunda afirma que a modernização brasileira, por opção dos atores políticos, excluiu o modelo liberal burguês e deu-se pela via autoritária, de cima para baixo, em que o Estado é construído pela coligação conservadora entre elites agrárias e setores político-burocráticos que controlam o aparelho estatal.

As dificuldades de implantação no Brasil desse encaminhamento tipicamente burguês e classista serão tema de estudo detalhado de um 
dos mais importantes intelectuais brasileiros, Florestan Fernandes, que originalmente utiliza as análises marxista e weberiana para tratar a questão. No livro A Revolução Burguesa no Brasil (1976), Fernandes afirma que os grupos economicamente dominantes no país estão condicionados a três características básicas. A primeira, já denunciada por Faoro, é a fraqueza e dispersão histórica do setor popular; a segunda é o que Fernandes chama heteronomia, um capitalismo de cunho fortemente dependente dos centros capitalistas internacionais e associado a eles; por fim, esses grupos fazem uma apropriação peculiar e ambígua das ideologias políticas estrangeiras do liberalismo e da democracia que não se reduz a imitações grotescas, mas também não absorve completamente tais ideologias.

Dessa conjunção de fatores resulta o Brasil não possuir uma dinâmica de classes. A heteronomia (a introjeção de valores e razões exógenos) conduzida por forças sociais autóctones configura uma associação destas - os setores industrial e comercial - com a oligarquia rural e com as burguesias dos países centrais, e veicula, internamente, uma situação de superexploração capitalista para compensar a adversidade da posição da burguesia interna como um sócio menor do capitalismo internacional; por outro lado, a debilidade histórica de um povo formado na condição escrava ou de profunda dependência pessoal e submetido a tal grau de exploração impossibilita uma dinâmica de luta de classes. Tudo isso faz das camadas proprietárias mais um estamento que instrumentaliza o Estado do que propriamente uma burguesia. Esse estamento, em um caminho inverso ao trilhado pela burguesia anglo-americana, se consolida controlando o poder político e, a partir daí, estabelecendo a dominação socioeconômica.

Este último aspecto é bastante próximo ao diagnóstico de Faoro (diretamente inspirado em Weber) do capitalismo politicamente orientado. Entretanto, Fernandes diverge de Faoro e, em alguns pontos, vai além, particularmente na questão da apropriação interna das ideologias modernizadoras liberais e democráticas e no resultado que tal apropriação terá em uma efetiva, porém lenta e gradual, modernização do Brasil.

Faoro enxerga em tais impulsos externos um vetor de mudanças econômicas e sociais, mas tanto os impulsos externos quanto as mudanças não conseguem tocar a estrutura política de dominação, pois são operados pelo estamento, que instrumentaliza, descaracteriza e do- 
mestica a agressividade inovadora das ideologias alienígenas e das mudanças socioeconômicas internas. Já Fernandes percebe em nosso liberalismo e em nossa democracia uma essência também política, melhor dizendo, político-ideológica, que, embora limitada, desempenha papel ambíguo diante da dominação política patrimonial - ao mesmo tempo que a reforça, a deslegitima. Ele, por exemplo, encara o liberalismo no Brasil como tendo, desde a Independência, uma funcionalidade importantíssima, isto é, de ser o vetor de veleidades, ideologias e ações modernizantes e antiestamentais. Na interpretação de Florestan Fernandes, nosso liberalismo tem validade política não só no momento da constituição do Estado nacional. A questão é que ele possui um campo socialmente restrito - só tem validade política efetiva "entre os iguais", ou seja, entre o senhoriato-, que funciona, concomitantemente, como construção, justificativa e reforço do poder desse senhoriato em face do restante do povo. Esse senhoriato, assim, tira vantagem tanto do moderno quanto do atraso, e veicula um tipo especial de democracia restrita ${ }^{10}$.

De qualquer forma, o estamento, em Fernandes, não "deglute" simplesmente, como em Faoro, a ideologia liberal e/ou democrática, filtrando novidades exógenas e colocando-as a serviço de justificar uma dominação tradicional, mas estabelece com ela uma relação dinâmica e contraditória em que ela é usada tanto a seu favor, quanto contra, ou seja, tanto para manter quanto para solapar o atraso da sociedade brasileira.

Outro autor que nega a predominância absoluta de valores pré-capitalistas em nossa sociedade é Jessé de Souza, que critica as idéias de uma "sociologia da inautenticidade" no Brasil. Faoro, junto com Sérgio Buarque de Holanda e Roberto DaMatta, é, de acordo com Souza, um dos mais destacados representantes dessa sociologia, cuja importância e ascendência são tão marcantes que influenciam o senso comum e a imagem que o brasileiro tem de si, cuja característica principal é enxergar o Brasil como uma alteridade atrasada e patrimonialista em relação, especialmente, ao modelo norte-americano.

Faoro veicula a "versão institucionalista" dessa sociologia, afirma Souza, consubstanciada na noção de patrimonialismo. Tendo como pano de fundo uma perspectiva liberal clássica e mediante um uso estático e tendencialmente a-histórico do conceito de patrimonialismo, Faoro esquematiza o desenvolvimento ocidental e transforma o 
exemplo norte-americano - em que a sociedade se forma antes do Estado e o florescimento das liberdades públicas e econômicas é concomitante - em uma regra, quando na verdade é uma excepcionalidade do desenvolvimento ocidental. O fato de os EUA terem formado a sociedade anteriormente ao Estado e não terem experimentado uma dominação tradicional transforma-o no grande parâmetro para caracterizar nosso subdesenvolvimento, uma contraposição que cega autores como Faoro para outras alternativas de desenvolvimento político e econômico a partir do Estado.

A força do exemplo norte-americano, transformando exceção em regra, desemboca, segundo Souza, na crença de uma excepcionalidade paulista dentro da história nacional. A defesa da "são-paulização" do Brasil como vetor do modelo americano de desenvolvimento capitalista perpassa a "sociologia da inautenticidade" e consolida-se na obra de Simon Schwartzman, cujo ponto central é a dicotomia entre São Paulo, com seu modelo político de representação, e o restante do Brasil, especialmente Nordeste, Minas Gerais, Rio de Janeiro e Rio Grande doSul, com o modelo de cooptação baseado no patrimonialismo. São Paulo, por ser capitania pobre e esquecida no período colonial, teria tido a sorte de se livrar do abraço sufocante do patrimonialismo português e teria se configurado como um desenvolvimento comparativamente mais igualitário. Essa noção, desenvolvida por Schwartzman, já está implícita em Faoro.

Em Os Donos do Poder, o conceito de patrimonialismo estamental transmuda-se na noção pura e simples de Estado interventor, acusa Souza. A presença ubíqua do estamento configura um elemento de intencionalidade e de fundo moralista - e empobrecedor - na teoria de Faoro, responsável pela própria força de convencimento de sua explicação: nossas mazelas seriam obra de uma "elite má" que controla o Estado. Assim, qualquer política estatal, mesmo de conteúdos e intenções díspares ou até opostos, recebe a chancela de estamental, e o Estado, como estimulador ou condutor da vida social, é, irremediavelmente, um mal em si. "A grande oposição ideológica do livro será aquela entre uma sociedade guiada e controlada pelo Estado, de cima, e as sociedades onde o Estado é um fenômeno tardio e o autogoverno combina com o exercício das liberdades econômicas" (Souza, 2000:172). 
A crença liberal clássica do Estado como um amortecedor da vitalidade social fica patente, segundo Souza, quando Faoro enxerga na transmigração da Corte lusa em 1808 apenas o velho estamento sob novo disfarce, não percebendo a verdadeira revolução política, econômica e social que aquele fato histórico teria posto em marcha. É na análise dos desdobramentos desse momento histórico tão importante que Souza, utilizando parcialmente o arsenal teórico de Gilberto Freyre, especialmente a obra Sobrados e Mucambos, vai acentuar a "europeização" do Brasil no século XIX como um processo de "modernização seletiva".

A modernização das sociedades capitalistas significa, para Souza, o processo pelo qual os indivíduos passam a ter sua conduta social regulada internamente, mediante a introjeção de regras de "civilida$\mathrm{de}^{\prime \prime}$, de imperativos de autocontenção. São vários, de acordo com a sociedade em que ocorra, os caminhos de construção da "civilidade". Seu impacto sobre elas não é uniforme nem se dá ao mesmo tempo; ao contrário, sucede de maneira seletiva, por meio da estratificação social - quer dizer, em cada país, é uma classe ideologicamente hegemônica que define o que é "moderno" ou "civilizado". Portanto, não há $o$ Ocidente, mas vários.

Além de não perceber esse fato, de que o complexo político-cultural ocidental é multiforme, a "sociologia da inautenticidade" é, para Souza, presa de um "culturalismo atávico", isto é, não vincula os valores culturais às questões da dinâmica institucional, que reproduz e consolida esses valores, e da estratificação social, que explica por que determinados valores se tornam dominantes em uma sociedade. As instituições e a estratificação social brasileiras jamais foram, declara Souza, mera continuação de Portugal, nem mesmo no início da colônia - o colono do Brasil, neto, filho ou mesmo nascido em Portugal, não era aquele lusitano que tinha sua quinta nos arredores de Lisboa. Valores não se transportam como a roupa do corpo, Souza escreve várias vezes, e os homens não os impõem ao seu meio; ao contrário, os atores são determinados pelo meio, reagindo, antes de tudo, a estímulos sociais, os quais não controlam.

Defendendo, pois, a singularidade de uma civilização que se formou "reagindo" ao seu contexto histórico particular, Souza afirma que houve, a partir de 1808, uma revolução modernizadora em nosso país, e que, já a partir do século passado, tem prevalecido apenas um 
código valorativo entre nós: o do individualismo moral universal, que é a base cultural da modernidade ocidental. Isso não quer dizer que o Brasil seja rico, moderno e democrático como os países centrais do Ocidente, que não haja códigos valorativos concorrentes e que o acesso a essa modernidade cultural seja igual para todas as classes e indivíduos. Significa que

“[...] tende a ser considerado justo, legítimo ou valorável, no nosso país, apenas as premissas, comportamentos, atitudes, leis, enfim, projetos coletivos de toda sorte, que sejam justificáveis segundo as normas que regem o código valorativo do individualismo moral ocidental [...] o único discurso legítimo capaz de unir as vontades é o discurso modernizador. Modernos são [...] os princípios do individualismo moral" (idem:254).

Admitindo a tese freyriana do patriarcalismo como o elemento determinante da sociedade brasileira colonial, Souza afirma que, com a Independência, os valores personalistas do patriarcalismo escravocrata foram sendo gradualmente sepultados. Aquela sociedade "difusamente oriental" em que os donos de terra e escravos tudo podiam vai sendo ocidentalizada. Entretanto, é por conta de uma característica dessa sociedade, apontada por Freyre em Casa-Grande \& Senzala, que surge a brecha para a ascensão social de um elemento "médio" tanto em termos econômicos quanto raciais, o mulato -, para este se afirmar e ser um vetor de modernidade impessoal. Essa característica é a forma muçulmana de escravidão, que, embora veicule uma atitude psíquica generalizada de sadomasoquismo entre senhores e escravos, possibilita uma aproximação entre ambos, particularmente sexual, e, portanto, uma superação pessoal da dureza da condição escrava. Além disso, o tipo mouro de escravidão faz com que os lugares sociais do patriarcalismo sejam funcionais e não essencialistas, ou seja, mais importante que ser branco e homem é sentir e agir como branco e homem, o que permite mulheres na função de patriarca ou filhos ilegítimos, geralmente de senhores com escravas, tratados como legítimos herdeiros.

A modernização do país, com a constituição de um Estado nacional e de um mercado incipiente em que mercadores e industriais europeus, sobretudo ingleses, trazem nova mentalidade, abre espaço para que alguns mestiços ascendam socialmente, vindo a participar da banda privilegiada da nova clivagem social que se formava, não mais sepa- 
rando brancos e senhores, de um lado, e negros e escravos, de outro, mas distinguindo entre quem partilha ou não valores ocidentais. A segregação e a marginalização sociais continuam, mas em outros parâmetros. Se antes de 1808 "branco" era quem funcionava como tal, após, "branco" passa a ser quem é "ocidental", "civilizado". Em ambos os casos, há um dado importante, traço da escravidão de tipo mouro: não importa tanto a cor e/ou as características propriamente biológicas do indivíduo.

Assim, o Brasil, para Souza, é Ocidente, sim. É Ocidente porque uma classe ideologicamente dominante incorpora o individualismo moral ocidental e transforma-o não só em parâmetro preponderante na sociedade, mas também em critério de diferenciação e exclusivismo social. Um Ocidente, como os outros, sui generis, por causa da sua herança escravista, e seletivo na esfera da estratificação social. Embora não faça, de forma alguma, juízo positivo da desigualdade social, Souza argumenta que o Brasil é moderno mesmo com ela; o problema é direcionar essa modernidade, já instalada entre nós, para o fim da desigualdade, já que o modo como o país se tornou moderno veiculou sua permanência.

Concordei com as seguintes idéias, basicamente interligadas, de Souza: 1) que a modernidade ocidental apresenta várias particularidades importantes conforme o local onde se desenvolva e instale; 2) que não há só um caminho para essa modernidade, pois se nos EUA a sociedade civil se conformou antes do Estado, isto não aconteceu em nenhum outro país, nem mesmo na Inglaterra, onde o patrimonialismo dos Stuarts foi batido política e militarmente no século XVII, que dirá na França, Japão, Alemanha, onde a via política e o Estado foram fatores importantes de modernização;3) que não se deve, portanto, generalizadamente e a priori, envilecer a política e o Estado e enaltecer a economia e a sociedade civil.

Entretanto, quanto à modernidade (específica) brasileira, Souza usa o enfoque cultural dos valores sociais para defender tal conceito. O Brasil seria moderno porque é culturalmente moderno, embora não de maneira uniforme. Ataca o "culturalismo atávico" da sociologia da inautenticidade. Provavelmente seu principal contraponto seja Sérgio Buarque de Holanda, que ele define como a figura mais influente, se não o fundador, dessa sociologia, e que tem uma posição essencialmente culturalista. Mas, ao aceitar o conceito de Freyre de "escravi- 
dão moura" para explicar nosso escravismo, Souza parece cair nesse mesmo culturalismo atávico que critica. Ele reitera que valores não cruzam oceanos nem se transportam como a roupa do corpo. Então, como aquele colono que, ao pisar na América, já não era o português das quintas lisboetas, pois já estava em contexto diferente, lança mão de um modo escravista típico da cultura muçulmana? (Uma civilização há tanto tempo enfraquecida na Ibéria, presente apenas subterrânea e secundariamente.) E note-se que essa herança cultural da escravidão muçulmana, para ele, permanece até o presente, tem a idade do Brasil: "a seletividade [da modernização brasileira] tem um vínculo secular, de quinhentos anos, com a escravidão muçulmana que se estabelece aqui" (idem:267). O interessante é que o próprio Sérgio Buarque de Holanda (1995:53) (e Souza o admite) também vincula a peculiaridade e a plasticidade de nosso escravismo - e de nossa cultura como um todo - à influência muçulmana, responsável, aliás, pelo europeísmo incompleto dos lusitanos. Nesse sentido, por que Sérgio Buarque de Holanda é um culturalista atávico e Gilberto Freyre e Jessé de Souza não o são?

Talvez Souza respondesse que a razão é dada pelo fato de ele, vinculando os valores da cultura à dimensão institucional e à seletividade ditada pela estratificação social, enxergar mudanças culturais no Brasil - apesar de a "escravidão muçulmana" influenciar até hoje. Nisso, no afã de apresentar uma revolução cultural, há outra impropriedade de sua teoria, ou melhor, um exagero, na medida em que, na substituição do personalismo patriarcal pré-moderno pelo individualismo moral burguês moderno, ele qualifica um processo de mudança cultural lento e ainda incompleto como uma guinada brusca e definitiva. É um exagero dizer que os valores do personalismo foram radicalmente contestados no século XIX, especialmente pela ascensão social do "mulato habilidoso", e que, já nessa época, "o vínculo de dominação passa a ser impessoal por referir-se a valores inscritos dentro da lógica do funcionamento das instituições fundamentais do mundo moderno, especialmente do mercado capitalista" (Souza, 2000:261, ênfases no original).

O personalismo, se realmente sofreu um abalo com o desiderato moderno/ocidental, não se tornou, de forma alguma, um valor secundário na vida brasileira por conta de alguns mulatos conseguirem ascender socialmente. O próprio Souza admite que essa ascensão era uma questão individual: 
"[...] esse acesso das camadas desfavorecidas é individual [...] indivíduos mestiços e mulatos tinham acesso a oportunidades efetivas de ascensão social, mas não os mestiços ou mulatos como grupo [...] isso acarretava uma 'cooptação' impessoal e objetiva do sistema enquanto todo, na medida em que possibilitava o ingresso dos membros mais capazes das classes subordinadas" (idem:262).

A questão é: como eram definidos, quais eram esses membros mais capazes? Por critérios objetivos ou pela cultura do favor? Para Weber, a promoção de indivíduos das classes subordinadas na escala social não configura, por si, superação do personalismo de sentido patriarcal ou patrimonial, pelo contrário, é uma atitude recorrente do poder central patrimonialista buscar diretamente na camada social dos despossuídos os seus favoritos pessoais, já que estes costumam ser bem mais fiéis que nobres e potentados. Não só o sistema racional-burocrático, mas também o patrimonialista se caracterizam por uma elegibilidade ampla de elementos dos estratos inferiores ao acesso social:

“[...] a burocracia, e também os funcionários puramente patrimoniais, baseiam-se na 'nivelação' social, no sentido de que, em seu tipo puro, só exigem capacidades pessoais - a primeira de caráter objetivo e especializado, os segundos, de caráter puramente pessoal - e desprezam toda diferenciação estamental" (Weber, 1992:819, tradução minha).

Há que salientar que, em Weber, a racionalidade técnico-formal não sepulta a aferição do valor pessoal, mas a transforma, na medida em que a submete a critérios universais e objetivos de mensuração de eficiência, contrários aos parâmetros particularistas e casuísticos da racionalidade material. Ou seja, o valor pessoal ainda é a tônica - a grande diferença encontra-se entre critérios particularistas e universalistas de sua aferição social. Há que definir, portanto, se os mulatos eram "habilidosos" no sentido particularista ou universalista. Souza afirma a segunda opção:

"[...] o conhecimento, a perícia, torna-se o novo elemento, que passa a contar de forma crescente na definição da nova hierarquia social. Nesse sentido, servindo de base para a introdução de um elemento efetivamente democratizante, pondo de ponta-cabeça e redefinindo revolucionariamente a questão do status inicial para as oportunidades de mobilida- 
de social na nova sociedade. Uma 'democratização' que tinha como suporte o mulato habilidoso” (Souza, 2000:242, ênfases no original).

Não é exatamente esse predomínio de qualidades pessoais para a ascensão social aferíveis de modo formal e universal o que atestam, na sociedade brasileira de ontem e hoje, Maria Sylvia de Carvalho Franco (que nega a sociedade de classes justamente pelo predomínio do particularismo definido pelo latifúndio autárquico), José Murilo de Carvalho (para quem a burocracia estatal imperial, um dos espaços de ascensão do mulato bacharel de Freyre/Souza, era marcada pela cultura do favor), Florestan Fernandes (que sublinha a prática das classes dominantes de tirar vantagem tanto do moderno quanto do atraso, ou seja, da dependência pessoal), Guillermo O'Donnell (que no artigo "Uma Outra Institucionalização: América Latina e Alhures" assegura que o particularismo e o clientelismo representam hoje, no Brasil e na América Latina, uma institucionalização paralela que impede o aprofundamento democrático), para não falar do próprio Faoro e de Sérgio Buarque de Holanda. Não é exatamente o que se vê hoje, para qualquer canto ou setor que se olhe da sociedade brasileira, urbanizada, industrial e capitalista, essas normas generalizantes de ascensão social por critérios universalistas preponderarem - não que estejam ausentes, mas dividem espaço e competem, corpo-a-corpo, com as normas (implícitas, muitas vezes) da cultura do favor.

Jessé de Souza jungiu, erroneamente, o personalismo (ou melhor, o particularismo) ao patriarcalismo despótico - daí, dessa arbitrariedade patriarcal, o caráter difusamente oriental que ele viu no Brasil colonial - e decretou, junto com o declínio do patriarcalismo havido com a Independência, o golpe de morte no personalismo, sem notar a continuidade deste com o patrimonialismo que se instauraria a partir de então.

Como ressalta Florestan Fernandes, no Brasil do século XIX, o antigo senhoriato rural escravista colonial viu-se incumbido da tarefa de construir um Estado e de negociar diretamente com o restante do mundo e foi nesse momento, e só a partir dele, que começou a vigorar, em sentido estrito, o patrimonialismo entre nós - juntamente, é certo, com princípios ideológicos liberais/burgueses, que tinham vigência ambígua e limitavam o patrimonialismo, mas não o anulavam.

Patrimonialismo é um conceito referente ao poder estatal. É preciso haver um Estado para haver patrimonialismo. Antes de 1808, patri- 
monialista, em sentido estrito, era o Estado português; a sociedade brasileira era patriarcal, Estado brasileiro não havia. Após essa data, o poder patriarcal certamente decai, pois passa a existir um Estado e um mercado instilando suas lógicas próprias naqueles "donos de pequenos mundos", mas essa decadência não veicula necessariamente uma modernidade racional-burocrática, justamente porque o mesmo destino não tem o personalismo. O enfraquecimento do patriarcalismo não pressupõe, de forma alguma, que o patrimonialismo terá o mesmo destino, pelo contrário, para Weber, o patrimonialismo, embora análogo ao patriarcalismo, no sentido de que o poder político se legitima na relação pessoal de piedade, representa uma superação deste. Souza não parece perceber isso, pois afirma que o Estado imperial

“[...] foi também um 'locus' importante dessa nova modernidade híbrida, já burguesa, mas ainda patriarcal, se bem que de um patriarcalismo já sublimado e mais abstrato e impessoal na figura do imperador pai de todos, e agora mais afastado portanto do patriarcalismo familístico dominante na colônia" (ibidem).

Ora, um patriarcalismo sublimado e estilizado no Estado e em um chefe político paternal é, precisamente, patrimonialismo. Admitir patrimonialismo, porém, seria, para Souza, admitir atraso, o atraso, absoluto, unívoco - e o intuito de sua teoria é justamente relativizar o atraso, assim como a modernidade. Relativizar tanto no sentido de desabsolutizar quanto no de relacioná-lo a conceitos definidos, discerníveis. Para ele, a noção de atraso, de não-modernidade brasileira, veiculada por Raymundo Faoro, Sérgio Buarque de Holanda e Roberto DaMatta é algo que adquiriu a força de um axioma, vago, indefinido, mas avassalador e que, além de não corresponder à realidade, tem conseqüências deletérias sobre a auto-estima coletiva do brasileiro.

Outro autor que se recusa a absolutizar o atraso e, especialmente, a não-ocidentalidade brasileira é Luiz Werneck Vianna. Para ele, a apropriação que Faoro - e outros, como Schwartzman - faz da obra de Weber termina por advogar que, para pôr fim à ordem neopatrimonialista brasileira, a dinâmica dos interesses individuais, manifestados na sociedade civil, seria fundamental. A sociedade, e não o Estado, seria o lugar da renovação. A principal crítica de Werneck Vianna, então, é que a instância do interesse individual, em um contexto não republicano, não cívico e antiestatal, não induz necessariamente a um círculo 
virtuoso social. A história recente brasileira é, para ele, o melhor exemplo. O interesse sem República e sem Estado "não veio a encantar o mundo dos brasileiros, pondo-os em um faroeste idílico propício à livre-iniciativa e à realização de trajetórias individuais venturosas" (Werneck Vianna, 1999:46).

A agenda republicana, portanto, é crucial para a efetiva democratização da sociedade brasileira, uma democratização que não deve menosprezar o papel do Estado, mas reformulá-lo, e que deve rever a avaliação histórica que apresenta a herança ibérica de maneira unilateralmente negativa e termina por pedir a superação do atraso pela liberação pura e simples do interesse individual.

\begin{abstract}
"Nessa hora em que se esgotam as perspectivas de boa sociedade contidas nas promessas feitas pelas interpretações hegemônicas sobre o Brasil, em que cabia ao moderno, no 'mercado' político e no mercado propriamente dito, dar passagem à liberdade e à igualdade, a relação entre atraso e República pode apontar um recomeço. Em primeiro lugar, porque os seus temas de fundo são o da ampliação da cidadania e o da defesa da sociabilidade [...] em segundo, porque importa uma reabertura da avaliação da nossa história [...] do que foi a nossa Ibéria, certamente uma república de poucos, embora tenha se mostrado apta à incorporação dos setores emergentes na sociedade brasileira, como se verificava no imediato pré-64" (ibidem).
\end{abstract}

\title{
O ARGUMENTO DE FAORO E O ESTADO BRASILEIRO NOS ANOS 90
}

Na conjuntura político-ideológica dos anos 90, contudo, o que prevalece é, inspirada, entre outras fontes, no patrimonialismo faoriano, a satanização do Estado e a estratégia de reorganizá-lo e refundá-lo sobre bases pretensamente "modernas", em que a categoria do "interesse individual" tem importância fundamental.

O Estado brasileiro, patrimonialista, sufocador das forças produtivas nacionais, é duramente atacado. O chamado neoliberalismo brasileiro dos anos 90 tem em comum com o liberalismo da República Velha e mesmo da Regência o fato de ser essencialmente depurado de conteúdo democrático. Liberalismo, em sentido estrito e em sua origem histórica, é bem diferente de democracia. A liberdade dos indivíduos, no liberalismo clássico, é entendida fundamentalmente como liberdade, perante o Estado, dos indivíduos proprietários. É a ideologia de liber- 
tação de uma classe social, a burguesia, em face do Estado patrimonialista aristocrático, absolutista e mercantilista. Já na democracia, a liberdade dos indivíduos é interpretada como liberdade de todos, diante não só do Estado como de outros indivíduos e grupos econômicos - neste último caso, postula-se a liberdade individual mediante a redução da desigualdade socioeconômica, via Estado.

Originalmente, os liberais burgueses eram opostos aos democratas. A fusão histórica liberalismo/democracia entre o final do século XIX e início do XX dá-se, principalmente, como resposta ao avultamento dos movimentos populares de inspiração socialista e comunista, que lutavam pela liberdade através da igualdade ${ }^{11}$. É significativo que, nas duas últimas décadas do século $\mathrm{XX}$, o arrefecimento do contraponto ideológico socialista/comunista para com a liberal-democracia seja acompanhado de um esvaziamento do conteúdo democrático e de um aumento do conteúdo liberal desse arranjo sociopolítico.

A aliança liberalismo/democracia, portanto, tem a ver com pressões sociais das camadas populares. Como estas são fracas no Brasil, a associação do liberalismo com a democracia e com o estabelecimento universal de direitos e garantias fundamentais é, quando muito, uma mera promessa, "para depois que as coisas se ajeitarem". O liberalismo, retomando a argumentação acima, segue, em linhas gerais, o mesmo caminho tomado na República Velha e na Regência: é um bom instrumento e uma boa justificativa para o domínio avassalador do poder privado de oligarquias econômicas sobre a massa da população. À oligarquia rural do regime pré-30 segue-se a oligarquia financeira do final do século: o despotismo privado substituindo o esta$\operatorname{tal}^{12}$.

Embora a explicação do liberalismo como máscara para o oligarquismo retire suporte ideológico do livro de Faoro, nosso autor nunca deixou de ser um crítico ferrenho do Estado brasileiro dos anos 90 e de apontar insistentemente seu caráter farsesco, recorrente na história brasileira, de patrimonialismo disfarçado de modernidade, utilizando a "modernidade" no que lhe interessa e desprezando sua característica fundamental, ainda não implantada neste recanto da América do Sul: o estabelecimento efetivo do Estado de direito, com seus elementos de previsibilidade e calculabilidade e sua racionalidade formal. Dessa forma, o que ocorre, argumenta ele, é uma modernização do país, que se opõe à verdadeira modernidade e a recobre - na primeira, $\mathrm{o}$ 
benefício é auferido apenas pelos setores dominantes; na segunda é que ocorre, como nos EUA e na Europa Ocidental, uma revitalização de toda a sociedade, revitalização ausente e/ou tolhida no Brasil.

O Brasil dos anos 90, afirma Faoro, vem sendo conduzido de forma patrimonial por uma elite dissidente, porém conservadora, que desconhece a categoria fundamental que é o Outro. Por não entender a alteridade, falta-lhe o componente ético em sua conduta, pautada apenas pelo sonho de ter acesso, a qualquer custo, aos padrões de consumo do Primeiro Mundo e pela defesa egoística de seus privilégios. No Brasil, a construção da cidadania e a defesa da coisa pública passam, necessariamente, pela anulação desses grupos.

Ironicamente, entretanto, são provavelmente tais grupos que se utilizam da recepção (canhestra) da obra de Faoro para defender uma "redução" do Estado que se configura, na prática, na redução de seu papel de distribuidor de renda e promotor da inclusão social, pela venda (criminosa pelo método, não por ela, em si) de suas empresas e pela colocação desse Estado à mercê dos rentistas (nacionais e internacionais) que vivem de financiá-lo a juros assombrosos. Embora a utilização do argumento faoriano seja, por um lado, distorcida, considero que este tipo de recepção do argumento se deve também a elementos nele presentes, especialmente a idéia de que uma sociedade de classes, com pleno predomínio do mercado, é o fio condutor da democratização. Faoro parece idealizar o potencial igualitário da sociedade de classes e do mercado e, ao mesmo tempo, desconsiderar que, se o Estado no Brasil atuou basicamente em prol da oligarquização, isto não quer dizer que não tenha sido, por vezes, vetor de inclusão e desenvolvimento social e, mais importante, que nunca possa sê-lo.

Embora, na minha opinião, o grande vilão da história brasileira no argumento de Faoro seja o estamento - os donos do poder -, este é apresentado tão imbricado com o Estado que respinga para este último, o "instrumento de trabalho" desse patronato, muito dessa vilania, o que acaba contribuindo para as críticas rasteiras e indiscriminadas ao Estado que grassaram nos anos 90. Quanto ao papel da sociedade estratificada em classes econômicas, está certo que a dinâmica histórica dos países ricos ocidentais apresentou o Estado de direito e a redução das desigualdades sociais após um processo que se iniciou com o liberalismo burguês e suas liberdades burguesas, passou pelo estabelecimento de classes populares que denunciavam a estreiteza do alcance 
dessa ordem e pela pressão e incorporação dessas classes à nova ordem liberal/democrática e, posteriormente, social/democrática. Entretanto, este foi um desenvolvimento histórico particular, não necessariamente tem que se repetir em outra época ou lugar. Se, no exemplo histórico, o estabelecimento de uma sociedade dominada pelo econômico, em que o primado é do "interesse particular", desembocou na democracia moderna, isto não quer dizer que esse amplo exemplo histórico nos deva levar a implantar a democracia somente através da primazia do mercado e do interesse particularista. Afirmar, como Faoro o faz, que na sociedade de classes o poder invariavelmente se projeta de baixo para cima, é generalizar e idealizar um caso histórico que poderia ter tido outro desfecho, contribuindo para a fetichização do mercado que assolou a vida brasileira nos anos 90.

(Recebido para publicação em outubro de 2002) (Versão definitiva em março de 2003)

\section{NOTAS}

1. "Piedade", aqui, não tem o caráter mais comum que se lhe dá, de pena ou caridade, mas o sentido de respeito filial pela pessoa do pater, intimamente associado à reverência pelo religioso, pelo sagrado, pelo tradicional. A piedade manifesta-se, segundo Weber, pelo sentimento de devoção puramente pessoal ao soberano que caracteriza o patrimonialismo, assim como o feudalismo.

2. É justamente essa caracterização do patrimonialismo brasileiro-e ibérico em geral - como unilateralmente forte, dominante, que tem sido contestada por certos autores. José Guilherme Merquior, por exemplo, afirma que "longe de ser um estado forte [...] o estado neopatrimonial de centralismo ibérico é intrinsecamente presa de pressões e bloqueios provenientes de sua colonização pela sociedade, ou melhor, pelos grupos socioprofissionais mais organizados" (1990:XVII). Observe-se, porém, a ressalva do próprio Merquior: não é toda a sociedade, mas os grupos mais poderosos e organizados que colonizam o Estado, boa parte do restante da sociedade não o coloniza, mas é colonizada pelo Estado patrimonial, que pode ser considerado forte, mas somente para subjugar esta parte, o setor popular, não organizado, da sociedade. Em comparação, porém, com o Estado estruturado em arranjo de poder racional-legal, vale a advertência de Merquior: "Basta um conflito nas Malvinas e logo se vê onde está o autêntico estado forte: se nas demoburocracias industri- 


\section{Rubens Goyatá Campante}

ais e liberais do Norte, ou nas tecnoburocracias industrializantes e iliberais do Sul" (ibidem).

3. Weber trabalha também com o conceito de "casta", outro tipo de estratificação social, ao lado da classe e do estamento. Entretanto, a casta, para Weber, representa um caso especial e extremo de estamento - um estamento "fechado", que se torna hereditário e, ao mesmo tempo, leva ao paroxismo o exclusivismo e o distanciamento social estamentais, proibindo, com freqüência, o casamento entre pessoas de grupos diferentes e também, assiduamente, jungindo os membros de um grupo a uma "profissão" ou atividade específica, transmitida hereditariamente. Assim, um estamento é, potencialmente, uma casta, e a casta é uma evolução de uma situação estamental de estratificação social.

4. A palavra "estamento" tem a mesma raiz etimológica de "estado" - status. Historicamente, estamento parece derivar dos estados pré-capitalistas, ou seja, as várias ordens e categorias, internamente coesas e externamente exclusivistas, em que se dividia a sociedade, regidas, em alguns casos, por estatutos próprios, as privatio legis. Bendix sustenta que "grupo de status" seria a tradução mais adequada do vocábulo alemão Stand usado por Weber, para quem o significado de estamento seria mais amplo que o de "estado", tipicamente europeu medieval, pois abrangeria quaisquer grupos sociais coesos, com suas subculturas e sua exclusão de outsiders. Segundo Faoro, o termo foi introduzido na sociologia moderna por Weber, mas já era usado por Marx e Engels, "ciosos do bom emprego do conceito Stand, comprometido com a realidade pré-capitalista - a burguesia moderna, atualmente uma classe, gerou-se do estamento (o 'terceiro estado' da política francesa). Clara, para eles, a distinção entre classe e estamento, que depois se esfumou, em grande parte devido à perplexidade dos tradutores franceses e de língua inglesa, por meio dos quais, no Brasil, se cultivou o pensamento sociológico [...]. O conceito de classes para Marx e Engels, compreende, sem negá-lo, o conceito de estamento" (Faoro, 1998:69, ênfases no original).

5. Enquanto os conceitos de dominação e de patrimonialismo têm seu desenvolvimento no marco da sociologia política de Weber, a distinção e a definição de classe e estamento, segundo Bendix, relacionam-se diretamente com sua sociologia da religião. Isto não significa, absolutamente, que tais conceitos, na teoria geral de Weber, sejam desconexos, antes o contrário. Quer dizer apenas que os primeiros correspondem a uma ênfase do autor na "ordem moral da autoridade baseada em uma crença na legitimidade", enquanto os segundos configuram a ênfase no estudo das "condições para a solidariedade baseadas em idéias ou interesses" (Bendix, 1986:230). Tais tipos de ênfase correspondem às três dimensões sobrepostas que compõem a vida social - a autoridade, o interesse material e os valores. Ou seja, no trato de temas como o patrimonialismo e a dominação, o foco de Weber está na dimensão da autoridade, embora as questões do interesse material e das orientações de valor (os ideais) jamais possam ser descartadas; por outro lado, quando se debruça sobre temas como as classes e estamentos, o foco muda para as outras duas dimensões: o interesse e os valores, embora, da mesma forma, não se descarte a questão da autoridade. Subjacente a essas preocupações está a concepção weberiana da sociologia como ciência cujo objeto é a ação social, o significado intersubjetivo, socialmente influenciado, que as pessoas emprestam a suas ações, pois, como diz Bendix: "Essas linhas de pesquisas sugerem que os homens em sociedade agem 
com os outros e contra os outros, com base em seus interesses materiais e ideais e que mantêm entre si uma relação de obediência e autoridade com base em acordos mútuos."(idem:231)

6. No meu entender, tal colocação de Paim precisa ser ponderada. É bastante razoável afirmar que no Brasil houve, desde o Império, um processo mais ou menos contínuo de modernização social, econômica, cultural. Parte deste foi assumido, ou mesmo instigado diretamente, pelas estruturas político-estatais. No entanto, apesar de possuir, inegavelmente, uma faceta moderna e de o Estado (patrimonial) brasileiro ter seu grau de responsabilidade por tal faceta, a sociedade brasileira, em termos de distribuição interna de poder, permanece marcadamente pré-moderna, e o Estado tem bastante responsabilidade sobre isto também. Até hoje não sobressai, em nosso país, uma oxigenação democrática do arranjo de poder (ainda marcadamente patrimonial) que legitime e organize o poder político em bases amplamente públicas, em vez das bases privativo-elitistas que temos experimentado.

7. O argumento de Elisa Reis baseia-se na teoria de Barrington Moore sobre as vias de modernização das sociedades e o papel que o mundo agrário teve em tais processos. Reis, porém, adverte que utiliza tal fonte introduzindo nela duas alterações teóricas essenciais para sua aplicação ao caso brasileiro: a inclusão do Estado como um ator político em si, e a explicitação das opções disponíveis e escolhidas pelos atores políticos. Quanto ao legado dos teóricos do patrimonialismo como Faoro e Schwartzman, ela afirma que se a herança jurídico-política do patrimonialismo lusógeno é um elemento importante na compreensão do autoritarismo brasileiro, tal herança foi permanente e dinamicamente recriada na conjuntura social agrária brasileira.

8. Ou seja, não apenas elites patrimoniais de regiões economicamente decadentes apelavam para a interferência não liberal do Estado a seu favor - os "modernos" cafeicultores paulistas também "abandonaram [Adam] Smith [...], quando se tornou claro que a autoridade do Estado podia ser ativada para neutralizar condições de mercado desfavoráveis" (Reis, 1982:342). Entre as ações do Estado a favor da oligarquia cafeeira paulista, a autora lembra o subsídio estatal à imigração e a interferência para a manutenção dos preços do café. Mediante a solução da imigração com fundos públicos, Reis assevera que a oligarquia paulista concretizou uma aliança reacionária com as oligarquias nordestinas no sentido de evitar a competição interna por mão-de-obra, mantendo o mercado do Centro-Sul fechado às populações nordestinas, que continuaram submetidas a formas extra-econômicas de coerção. Tal aliança ensejou um encaminhamento conservador a um acontecimento potencialmente revolucionário como a abolição da escravatura.

9. No meu entender, não há incoerência em se diluir a fronteira entre as esferas pública e privada e ter como conseqüência uma centralização de poder - não se se opera em um arranjo patrimonial de poder baseado, entre outras coisas, justamente em tal diluição. A centralização ou a descentralização política, tendências em constante tensão em tal arranjo, não são os seus fatores cruciais - o que importa, fundamentalmente, é o conteúdo privado do poder político, mesmo que tal conteúdo opere em um contexto visto como "estatista" ou propriamente "privatista". Não se está, de forma alguma, a dizer que não há a mínima diferença, por exemplo, entre contextos sociopolíticos como o do governo Vargas ("estatista") e o da República Velha 


\section{Rubens Goyatá Campante}

("privatista") - o que se está a salientar é que, apesar de suas singularidades, em ambos não se instaura a res publica, ou não se instaura em sentido amplo, transcendendo o nível estritamente oligárquico e veiculando a impessoalidade legal-universal. A autoridade "pública" que Reis viu paradoxalmente fortalecida pelo federalismo da República Velha não era propriamente "pública", nesse sentido. Uma obra como a de Reis tem, entre outros, o mérito de destacar, no período estudado, a centralização germinando na aparente descentralização política. Vários outros autores, por sua vez, apontaram, pertinentemente, o aspecto privatista de períodos centralizadores como o governo Vargas e a ditadura militar pós-64. Como afirma Guimarães: "o fato é que a tradição política brasileira, submetida às pressões do privatismo e estatismo, não chegou a construir uma sólida esfera pública, de universalização de direitos e democraticamente controlada pela sociedade" (2000:35). Ou seja, entre estatismo e privatismo, é a res publica que sai perdendo sempre.

10. A democracia, assinala Fernandes, assim como o desenvolvimento capitalista, não é unívoca, não é "um valor universal". Não se deve, segundo ele, desvinculá-la de seu conteúdo de classe. Há a democracia socialista, expressão do domínio das classes trabalhadoras; a democracia burguesa, em que, apesar da hegemonia burguesa, as classes subalternas participam positivamente da arena política; e, finalmente, a democracia restrita, de cunho marcadamente antipopular - nesta, as massas populares absolutamente não participam, nem sequer no marco da hegemonia burguesa. O Brasil caracteriza-se por apresentar o último tipo, no qual os princípios liberais, assim como os democráticos, ao contrário do que diz Faoro, funcionam efetivamente, porém apenas dentro de e para uma camada proprietária, constituindo, segundo Fernandes, não uma condição geral da sociedade, mas um recurso de eficácia e continuidade da dominação estamental - ao mesmo tempo, contudo, em que são uma brecha para a própria contestação da dominação estamental, por parte de setores sociais médios e da própria elite.

11. É interessante o comentário que Giovanni Sartori (1988:452) faz a respeito do "casamento", ocorrido em meados do século XIX, entre democracia e liberalismo, tendo Tocqueville como um dos "padrinhos" intelectuais: na década de 1830, democracia e liberalismo pareciam, a Tocqueville, adversários; após o estremecimento provocado pelos movimentos sociais de 1848, o pensador liberal francês passa a atribuir ao socialismo o componente antiliberal e despótico da democracia, e ao liberalismo a parte não despótica, passando, portanto, em reação à ameaça que via nos movimentos sociais e no socialismo, a defender a democracia liberal.

12. A desconstrução e omissão do Estado são, no entanto, conduzidas centralmente, da cúpula do Estado, sob o império de uma racionalidade jurídica casuística e de práticas e alianças políticas antidemocráticas, que incluem mesmo parte dos quadros do regime autoritário anterior. Descentralização e desestatização, portanto, não seriam as palavras certas para definir esse movimento. Como salienta Décio Saes no livro República do Capital (2001), para que um Estado promova a privatização, desregulamentação e abertura econômica internacional, ele deve, paradoxalmente, possuir uma grande capacidade política e exercer uma ação regulamentadora forte - a operação de redefinição da atuação do Estado tem de ser conduzida por um poder estatal forte. O que se chamou no Brasil dos anos 90 de neoliberalismo significa, portanto, a redução de políticas de: a) autonomia econômica nacional; b) bem-estar 
e proteção social; c) pleno emprego; d) mediação de conflitos socioeconômicos. Para se alcançar tais objetivos, não pode haver, de forma alguma, redução do poder estatal.

\section{REFERÊNCIAS BIBLIOGRÁFICAS}

BENDIX, Reinhard. (1986), Max Weber, um Perfil Intelectual. Brasília, Ed. Universidade de Brasília.

CARVAlHO, José Murilo de. (1980), A Construção da Ordem - A Elite Política Imperial. Rio de Janeiro, Campus.

CORDEIRO, Leny e COUTO, José Geraldo (orgs.). (2000), Quatro Autores em Busca do Brasil: Entrevistas a José Geraldo Couto. Rio de Janeiro, Rocco.

FAORO, Raymundo. (1993), "A Aventura Liberal numa Ordem Patrimonialista". Revista USP, no 17 , pp. 14-29.

. (1998), Os Donos do Poder - Formação do Patronato Político Brasileiro (13ª ed.). São Paulo, Globo.

FERNANDES, Florestan. (1976), A Revolução Burguesa no Brasil (2ª ed.). Rio de Janeiro, Jorge Zahar.

FRANCO, Maria Sylvia de Carvalho. (1976), Homens Livres na Ordem Escravocrata (3a ed.). São Paulo, Ática.

FREYRE, Gilberto. (1990), Sobrados e Mucambos ( $8^{\underline{a}}$ ed.). Rio de Janeiro, Record.

GUIMARÃES, Juarez Rocha. (2000), "O Claro Enigma da Política Brasileira”. Revista do Legislativo (edição especial - Brasil 500 anos), pp. 30-39.

HOLANDA, Sérgio Buarque de. (1995), Raízes do Brasil (26aㅡ ed.). São Paulo, Companhia das Letras.

MERQUIOR, José Guilherme. (1990), Rousseau e Weber: Dois Estudos sobre a Teoria da Legitimidade. Rio de Janeiro, Guanabara Koogan.

O’DONNELL, Guillermo. (1996), “Uma Outra Institucionalização: América Latina e Alhures". Lua Nova, no 36, pp. 5-33.

PAIM, Antônio. (1998), A Querela do Estatismo. Brasília, Senado Federal.

REIS, Elisa M. P. (1982), “Elites Agrárias, State-Building e Autoritarismo”. Dados, vol. 25, no 3, pp. 331-348.

SAES, Décio. (2001), República do Capital. São Paulo, Boitempo.

SARTORI, Giovanni. (1988), Teoria de la Democracia Revisitada. Madrid, Alianza Editorial. 


\section{Rubens Goyatá Campante}

SCHWARTZMAN, Simon. (1988), Bases do Autoritarismo Brasileiro. Rio de Janeiro, Campus.

SOUZA, Jessé de. (2000), A Modernização Seletiva - Uma Reinterpretação do Dilema Brasileiro. Brasília, Editora Universidade de Brasília.

URICOECHEA, Fernando. (1978), O Minotauro Imperial: A Burocratização do Estado Patrimonial Brasileiro no Século XIX. Rio de Janeiro, Difel.

WEBER, Max. (1982), Ensaios de Sociologia (5 ${ }^{\underline{a}}$ ed.). Rio de Janeiro, Guanabara Koogan.

(1992), Economía y Sociedad. Buenos Aires, Fondo de Cultura Económica de Argentina.

WERNECK VIANNA, Luiz. (1999), “Weber e a Interpretação do Brasil”. Novos Estudos CEBRAP, $\mathrm{n}^{\circ}$ 53, pp. 33-47.

ZABLUDOVSKY, Gina Kuper. (1989), La Dominación Patrimonial en la Obra de Max Weber. Cidade do México, Fondo de Cultura Económica.

\section{ABSTRACT \\ Patrimonialism in Faoro and Weber and Brazilian Sociology}

The objective of this article is to study the content and reception of Raymundo Faoro's work in Brazil, comparing it to his Weberian theoretical matrix and postulating that his concept of patrimonialism limits the original explanatory capacity by linking patrimonialism merely to a centralized and powerful political structure and by overlooking the facet of its decentralization and state inoperability. The biased utilization of Weberian theory influences the critiques of Faoro's work, which err when they move from (pertinently) contesting the author's heavy and fatalistic interpretation of Weber to challenging the explanatory potential of the Weberian concept per se. The article thus presents other authors who take a more variegated approach to the theme of patrimonialism, without denying its interpretative importance. Finally, the article emphasizes how Faoro's ideas contributed (unintentionally, by the way) to shaping an anti-statist, privatist, and ultimately oligarchic political culture in recent Brazil. In Brazil, the concept of patrimonialism has exerted a seminal influence and sparked controversies and distinct interpretations - thus, the best stance in such an important discussion is to attempt to clarify the concept, and that is what we have attempted to do, within our limitations.

Key words: Brazil; society; political power; patrimonialism; stratum; Weber; Faoro 


\section{RÉSUMÉ}

\section{Le Droit au Patrimoine chez Faoro et Weber et la Sociologie Brésilienne}

Le but de cet article consiste à étudier le contenu et l'accueil de l'œuvre de Raymundo Faoro au Brésil en la comparant à sa matrice théorique weberienne et en postulant que sa conception de droit au patrimoine restreint sa valeur d'explication originale lorsqu'il assimile le droit au patrimoine à une simple structure politique centralisée et puissante tout en négligeant son aspect de décentralisation et d'inefficacité étatique. L'usage inexact de la théorie weberienne influence les critiques à Faoro, qui se trompent quand elles quittent l'objection (pertinente) pour viser l'interprétation pesante et fataliste de l'auteur jusqu'à la puissance explicative de la conception weberienne en soi. On y présente d'autres auteurs qui abordent le thème du droit au patrimoine de façon plus nuancée, sans lui dénier son importance comme interprétation. Enfin on fait remarquer l'apport (involontaire, on en convient) des idées de Faoro dans le modelage d'une culture politique anti-étatique, plutôt privée et, à la limite, oligarchique dans le Brésil actuel. Le concept de droit au patrimoine exerçant au Brésil une influence fructueuse et suscitant des discussions et des interprétations diverses, on a souhaité ici l'éclairer, bien que de façon limitée.

Mots-clé: Brésil; société; pouvoir public; droit au patrimoine; groupes sociaux; Weber; Faoro 